\title{
Tradícia otvorená k premýšl’aniu Súbor príspevkov, ktoré vznikli v súvislosti s oslavami Teologickej fakulty Trnavskej univerzity v Trnave so sídlom v Bratislave
}

editorial

Predložený súbor štúdií bol napísaný z príležitosti trojitého jubilea Teologickej fakulty Trnavskej univerzity v Trnave so sídlom v Bratislave. V roku 2017 Teologická fakulta oslavuje tri výročia: od 5. októbra 2016 - 75. výročie založenia Inštitútu sv. Alojza, z ktorého vznikla v roku 1997 Teologická fakulta; 23. októbra 2017 - 20. výročie založenia Teologickej fakulty; 1. decembra 2016 - 15. výročie založenia a činnosti vedeckovýskumného pracoviska Teologickej fakulty: Centrum spirituality Východ - Západ Michala Lacka so sídlom v Košiciach.

Teologická fakulta myšlienkovo, ako aj obsahovo nadväzuje na pôvodnú, jezuitmi založenú Teologickú fakultu 1635-1777. ${ }^{1}$ Zároveň je silne prepojená so Slovenskou provinciou Spoločnosti Ježišovej.

Z hladiska kánonického a reholného práva je Teologická fakulta pokračovaním Teologického inštitútu svätého Alojza Spoločnosti Ježišovej na Slovensku, zriadeného autoritou generálneho predstaveného Spoločnosti Ježišovej v roku 1941 ako reholné štúdium posvätných náuk. Slovenská provincia Spoločnosti Ježišovej už v tridsiatych rokoch pripravovala popri iných apoštolských podujatiach aj zriadenie teologického učilišta pre reholných bohoslovcov. 5. októbra 1941 oficiálne začal svoju činnost’ Teologický inštitút svätého Alojza v Banskej Bystrici. Svojou povahou sa Teologický inštitút zameriaval na to, aby členovia inštitútov zasväteného života, najmä tí, čo sa pripravujú na kňazskú službu, ako aj veriaci laici dosiahli primerané vzdelanie v náuke Cirkvi, a tak sa formovali pre službu v Božom lude.

1 Porov. J. Dolınskx́, „Dejiny jezuitskej Teologickej fakulty Trnavskej univerzity v rokoch 1635-1777,“ Duchooný pastier 97, č. 2-3 (2016): 115-121; J. Dolinskx́, „,The Faculty of Theology 1635-1777," in The History of Trnava University 1635-1777, 1992-2012, Trnava: Typi Universitatis Tyrnaviensis. The Institute of History of Trnava University in Trnava, 2014, s. 79-103. 
V roku 50. výročia založenia, 30. septembra 1991, Teologický inštitút sv. Alojza Spoločnosti Ježišovej na Slovensku obnovil svoju verejnú činnost'. Akademický rok 1994/95 sa začal slávnostným Veni Sancte 26. septembra 1994 v Trnave. Po slávnostnej sv. omši v katedrálnom Chráme sv. Jána Krstitel’a sa v budove Trnavského divadla konalo slávnostné začlenenie Teologického inštitútu sv. Alojza Spoločnosti Ježišovej na Slovensku do Trnavskej univerzity.

Popri riadnom chode Teologického inštitútu intenzívne pokračovali prípravy na zriadenie Teologickej fakulty Trnavskej univerzity v Trnave. Po viacerých náročných administratívnych krokoch bola napokon fakulta zriadená ku dňu 23. októbra 1997.²

Teologická fakulta si oslavou trojitého jubilea pripomína svoju tradíciu, ale aj súčasné smerovanie v kontexte tak univerzálnej, ako aj miestnej slovenskej Katolíckej cirkvi i v rámci Slovenskej republiky. Sprevádza ju motto, ktorým vyjadruje svoju podstatu: Tradícia otvorená premýšlaniu. Týmto vyjadrujeme to, že vo filozofickom, teologickom a sociálnom bádaní sa opierame o pravú katolícku Tradíciu a pritom si uvedomujeme dôležitosṫ otvoreného premýšlania, ktoré chráni pred uzatvorením sa do myšlienkového geta.

Miloš Lichner SJ

2 Porov. L. Csontos, Verejne aj utajene: Jezuiti na Slovensku v rokoch 1919 až 2014, Olomouc: Refugium Velehrad-Roma, 2015. 